\title{
Philosophy of Education by T. Jefferson
}

\author{
Elena Kuzina \\ Department of Sociology \\ Financial University under the Government of the Russian Federation \\ Moscow, Russia \\ E-mail: urticaferox@yandex.ru
}

\begin{abstract}
The article deals with the analysis of the philosophy of education by Thomas Jefferson (1743-1826), who is called "the great American," the apostle of independence and freedom. In his homeland he is considered as one of the founders of American culture and an outstanding figure of the Enlightenment. The author analyses his contribution to the educational system in the United States, which is a practical realization of the theoretical positions of the philosophy of this outstanding thinker. T. Jefferson's philosophy of education is based on his understanding of political philosophy, democracy and man. It is education that is for Jefferson the key tool for building and developing a "virtuous republic", and the principles of education laid by this thinker and politician are the basis for the social reproduction of the American citizen.
\end{abstract}

Keywords—philosophy of education; Jefferson; American philosophy; political philosophy; social philosophy; ethics

\section{INTRODUCTION}

Thomas Jefferson (1743-1826) occupies a special, exceptional place in US history. He was one of the founding fathers of new America, the author of the draft of the United States Declaration of Independence, the third president of the United States, an opponent of slavery. He was also an outstanding representative of the American Enlightenment, the founder of University of Virginia, and was the head of the American Philosophical Society. He is called "the great American," the apostle of independence and freedom. In any of the modern textbooks on the history of political doctrines, he is mentioned as one of the most important figures in the American political thought of the Enlightenment [2].

Thomas Jefferson has gone a long way in life. He was born in the family of a landowner. According to biographers, from an early age he was noted for his curiosity, excellent abilities and diligence. He studied at least five foreign languages, played the violin well. He gained huge experience in politics: at the age of 26 he was elected to the Legislative Assembly of the State of Virginia, at 32 he became the delegate of the historic Continental Congress in Philadelphia and on behalf of the Congress Commission wrote the original text of the Declaration of Independence [3].

Jefferson's personality was formed under the influence, above all, of the culture of Antiquity, which he worshiped, and the Renaissance. He loved the poetry of Homer and Virgil, admired the philosophy of Socrates, Democritus, Epicurus and Seneca. As for modern philosophers, he was fascinated by the writings of Bacon and especially by Locke, as well as by Rousseau, Voltaire, Montesquieu, and others. As a person, Jefferson stood out for his encyclopedic universalism. At the same time, he sought a stoic worldview that would help him to mitigate the results of human disappointment, to maintain health, a calm and optimistic attitude to life. In this he was helped by a combination of reasonable epicureanism and stoicism. Jefferson's views were generally determined by the values of the Enlightenment, in which he was formed as a thinker and as a politician. He believed that reason and common sense, that accompany it, are the only reliable judges in the matters of truth, that human convictions and rules of behavior can and should be based on them only [4].

\section{FOUNDATIONS OF THE PHILOSOPHY OF EDUCATION}

The topic of education in Jefferson's writings is not the main one considering the volume, place and attention which it occupied. In this regard, political philosophy and democracy are the main ones. It is not without reason that he is called the father of American democracy and modern democracy in general. Jefferson was actively engaged in education problems at the young age. Then he returned to them, but already in the older age, when he completely stepped away from public affairs and actually was permanently staying in his house-estate of Monticello. Nevertheless, as far as the importance of the philosophy of education is concerned, it is close to political philosophy and democracy, they are organically linked, mutually complementing and reinforcing each other. Jefferson viewed politics and democracy through the prism of education and ethics. He noted that one of his main goals was the construction of a "virtuous republic" in America.

In general, Jefferson's philosophy of education rests on his understanding of political philosophy, democracy and man.

Jefferson's political philosophy is based on two ethical propositions: the goal of life is individual happiness; the state's goal is to ensure and to increase this happiness. His democracy means "the concept of man and society, in which the principle of "life, freedom and pursuit of happiness» applies to everyone regardless of his social status, age, sex or skin color" [5]. Democracy for Jefferson is exemplified by the democracy of the Greek polis, which was small in size and number of citizens and therefore allowed everyone to 
participate directly in discussion, decision-making and management. It was a direct democracy, and it was this kind of democracy, the "democracy of participation," which attracted Jefferson most, although he also valued representative democracy. Hence the high and decisive importance that he attached to education since Greek education was the best in the world. He also believed that "Greece was the first civilized country to give an example of what a person should be like" [6].

In his understanding of man, Jefferson relied on the theory of moral feeling, according to which this feeling, or "moral instinct," is innate, it is given to all. Moral feeling perceives society as the natural home of man. Jefferson identifies in it three interrelated properties: 1. The person's ability to moral choice, that is, the knowledge of good and evil and the freedom of choice of good, based on this knowledge. 2. An innate ability to identify yourself with other people, the feeling of sympathy for others' concerns and sufferings. 3 . The natural feeling of justice, which results from a combination of these two properties, is the one that makes social life possible and benevolent [7].

In contrast to liberalism, which insisted that a man by nature is a separate, isolated and independent being, Jefferson reasonably believed that a man by his nature is a social and political being. "Man, by his nature is adapted to society, and society with its conveniences is adapted for man" [8]. A special role is played by virtue, the essence of which, according to Jefferson, is to do good to others.

Jefferson especially emphasized the importance of a feeling of justice, considering it the main one. Here he completely disagreed with the liberal philosophers who viewed justice as an artificial construction based on agreement. Jefferson called it an innate instinct, believed that a moral feeling is part of our natural constitution, as well as feelings of touch, vision or hearing. In his opinion, the existence of an innate ability for justice is not at all refuted by its absence in some people, since "the lack or imperfection of the moral feeling in some people, like the lack or imperfection of the feelings of sight or hearing in others, does not prove that this is a general characteristic of the human race" [9]. In addition, the innate feelings of the just and the unjust, like other features, are in many ways inclinations and abilities that need education, upbringing and development. Moral potencies require their disclosure. Jefferson believed in a person's ability to develop a moral feeling, if its lack was revealed, through moral education.

The duty of moral education of people Jefferson assigns to philosophers, clergymen and legislators. A political structure that provides both education and practical participation in the management of society is the democracy of direct participation.

Thus, according to Jefferson, the moral feeling, which creates the basis of human society, needs society for its education and development. Moral behavior is neither congenital, nor the one for which only society is responsible. Responsibility is borne by both - man and society. In the first, a moral feeling is born, and society must cultivate and improve it.
In his approach to society Jefferson fully gives his sympathies to the people and ordinary citizens. He was very critical of aristocracy, that is economically and politically privileged groups, who believed that social inequality was natural, legitimate and just, that the government, who has money and property, should rule. Jefferson believed that one can recognize only one aristocracy - the aristocracy of genuine virtues, the aristocracy of naturally gifted, creative people.

Jefferson quite reasonably made the thesis that the people are the highest social authority, which is always right. He at the same time relied on his concept of human nature, in which he treated man as a social being, destined to live in a community and demanding a political society, in order to cultivate and to develop the social nature inherent in a man. The second basis of his concept was the idea about politics as a thoughtful development of social abilities of citizens through their direct participation in the life of the community and in the ruling process. He also relied on his ethical concept, emphasizing that the values of social cooperation and harmony are best realized in democratic self-government.

All this found continuation and development in his philosophy of education.

\section{AIMS AND OBJECTIVES OF EDUCATION}

In his views on education, Jefferson relied on many sources. From the French, he borrowed the idea that education must be egalitarian, secular and based on philosophy. He studied the works of Condorcet, Charron and Turgot, and was influenced by such scholars and public figures as Lafayette, Cuvier, Buffon, and others. Jefferson also read the works of many Britons and Americans such as Adams, Locke, Stuart, Price, Randolph, Henry.

Jefferson believed that education should be scientific and useful. All his life he insisted that in college you need to learn Latin and Greek. Many of his positions and thoughts on education Jefferson formulated in his "Bill on the universal dissemination of knowledge" (1779). He suggested dividing each county into districts, allowing each of them to have elementary schools. One of the bills suggested the secularization of the Virginia college and the addition of an in-depth study of science to its curriculum. Another bill proposed the creation of public libraries in Virginia for students, elected officials and talented citizens. One more bill included the creation of trustees' councils in the districts. Jefferson had special hopes on this bill, because in his opinion, it was the basis for preserving freedom and happiness in a true republic. This bill was also a key one for reforms aimed at educated and prosperous citizens. Of all the proposed bills, only one, which suggested prohibiting the state patronage of any religion, was adopted.

Jefferson deeply believed in people and citizens. At the same time, his faith in people was not unconditional. He never strongly insisted that the government of the people and for the people can be created and will work well. His experience told him that a government in which officials were not elected by people and owed nothing to them, in fact did not work, that is, they did not meet the needs of people at 
all. For citizens' rights to be respected and protected, and for rulers not to rule only in their own interests, all citizens need basic education.

Jefferson believed that education and prosperity of people are closely related. He singled out two levels of education: for skilled and unskilled workers. Unskilled workers are divided into farmers, laborers and artisans, who need business support and improvement of their position. Therefore, for them access to primary education is enough. Skilled workers need access to colleges and universities.

Jefferson believed that the duty of the authorities was to give every citizen the opportunity to get education proportional to the conditions and life aspirations. His needs are not just his personal business. According to Jefferson, people are social creations, and republics must be progressive. And then citizens have political obligations. Education is extremely important. In order to constantly improve people's condition, what we naively hope for and believe in, we need education - the main instrument of efficiency. In order to build and live in a sustainable, prosperous democracy, all citizens should know and accept their common role as far as they are able to do this.

\section{IMPLEMENTATION OF THE SYSTEM OF EDUCATION}

Jefferson understood that in order to develop both political participation and moral progress, education must be a system. He singled out six principles of such a system [10]:

- Basic education should be accessible to all.

- Education must be financed through taxes.

- Education must be free from religious dictate.

- The educational system must be under the control of local authorities.

- The highest level of education is complemented by free scientific research.

- Intellectually developed (talented) people should be able to get the highest level of education at public expense.

Only the system of education can give all citizens the very education that meets their needs: ordinary people get general education; intellectuals get education, corresponding to their specific needs. In the spirit of Bacon, who believed that knowledge is power, Jefferson clearly stated: knowledge is power, knowledge is safety, knowledge is happiness.

In general, as shown by observation, human capabilities and abilities remain very undeveloped. Therefore, education must use and develop untapped human potential in a morally correct direction. In this regard, we can recognize that a wild, un-cultivated tree can give only bitter and sour fruit and nothing can be done about it. However, we know that if a new tree is planted on a wild trunk, it will produce something quite suitable and of a higher quality. Similarly, education seems to vaccinate a new person and turns in his nature the features that were evil and vicious into virtuous qualities.
Human perfection, according to Jefferson, is something like a better standard of living, which implies not only progress in human health and productivity through discoveries and inventions that reduce labor costs, but also moral improvement. Moral improvement is more important than the development of rationality, and moral sensitivity is a trait of people, who are involved in real life.

At the same time, Jefferson considers morality lessons unnecessary, if not harmful. He argues that such occupations are the waste of time, since moral behavior is not a matter of reason. Nevertheless, although the moral feeling is innate, its development and improvement is the task of education.

The first stage of education is not the most appropriate time for training critical thinking, since the mind is not sufficiently developed. This is the time when children must remember historical facts in order to later critically reinterpret them.

So moral education is less about the suggestion of moral principles, but rather how to forget to put faith in the place of moral feeling, in order to determine how to act correctly without the corrupting influence of reason or the pressure of the elders. Since rationality depends on morality, education must be useful. It must foster effective civic participation and maintain political stability.

Jefferson always insisted on the practicality of education, because his approach to knowledge was Baconian: the development of knowledge, according to Bacon, should be based not on random discoveries, but it should be a premeditated process [11]. For example, Jefferson considered the discovery of E. Jenner a smallpox vaccine more valuable than the discovery of the circulatory system. However, every scientific study is potentially useful. In this regard, Jefferson argued that not a single discovery is fruitless, it always serves as a stepping stone to something else. Putting utility at the center of his philosophy of education, he understood utility in the broadest sense of the word. A full-fledged education, in his opinion, will create a person who will be useful to society in all ways, "... -useful because intelligent, cultured, well-informed, technically competent, moral (this, particularly), capable of earning a living, happy, and fitted for political and social leadership" [12].

Utility implies social and political activity. Outstanding and gifted people will contribute to the development of society, participating in the life of society, occupying prominent positions in politics. Ordinary citizens have the opportunity to make more modest contributions, for example, to fulfill civil duties, participate in the militia, vote and observe the activities of deputies. After all, education for Jefferson is the way to live. Its goal is to give people the tools they need in order to be self-sufficient, free and happy. For Jefferson, education does not end with school. Man always moves forward in the constant process of education. A narrow professional who graduated from a technical college only and locked himself in his narrow specialty was a curse for Jefferson. Education must be encyclopedic for the sake of human freedom and happiness. 
In Virginia of the 18th century education was limited mainly to home-based education of wealthy children given by private mentors. Jefferson set himself a much more grandiose task: to create such a system of education, which that would provide mass education at public expense. In 1818, Jefferson put forward a multilateral and detailed program for the deep reform of Virginia education system, which developed and completed his thoughts and research of previous years. Jefferson could clearly picture the expected political and practical effect of proposed by him system of education. The proposed reform included three parts. The first of them assumed the introduction of universal free primary education in the state. To do this, all counties were divided into districts, each of which was to build a free elementary school, where for three years they would teach reading, writing, ancient and new history, geography and arithmetic. Here's how it is set out in "A Bill for the More General Diffusion of Knowledge 18 June, 1779".

"At every of these schools shall be taught reading, writing, and common arithmetic, and the books which shall be used therein for instructing the children to read shall be such as will at the same time make them acquainted with Græcian, Roman, English, and American history. At these schools all the free children, male and female, resident within the respective hundred, shall be entitled to receive tuition gratis, for the term of three years, and as much longer, at their private expense, as their parents, guardians or friends, shall think proper" [13].

Education at the same time was compulsory, since without a certificate of primary education no one could obtain citizenship rights. The second part concerned the system of colleges, which were planned to open nine, and which gave secondary education. Training in them was paid, however, for the most capable children from low-income families, an exception was made. The third part, the most detailed, was devoted to the creation of a university which gave higher education. The best, but poor students here also receive education at public expense. The university was to include a variety of faculties - from the architectural to the medical. It was supposed to teach "all useful sciences" - from physics to philosophy, ethics and economics. Among the subjects taught was theology, which Jefferson strongly opposed, but he was powerless. As a true enlightener, he believed that "the competence of religion must be strictly limited to its own questions" [14].

\section{CONCLUSION}

The ultimate goal of this carefully designed system of education was to contribute collectively to the development of inherent in a man abilities, and thereby to create a more just and harmonious society. Of course, following the spirit of republican traditions, the unified state system of education, which operated on the money of taxpayers, was controlled by them. "The key principle followed by American citizens who threw overboard cargo of tea in Boston was" there are no taxes without representation "[15].

Jefferson's philosophy of education is a logical continuation of his moral philosophy and, in essence, it is aimed at the practical cultivation in a man the theoretical ideas of moral philosophy. Equally Jefferson's philosophical views on education relied on political philosophy, too, since he believed that the education and prosperity of people are closely related. Therefore, Jefferson considered it necessary to create a system of mass public education. At the same time, Jefferson was not an egalitarian, considering it necessary to have two levels of education, focused on two social groups (it would be incorrect to call them strata, because this concept appeared much later). The basic mass of the population needs basic school education, whereas for skilled workers colleges and universities are needed. Education, according to Jefferson, should be practically useful and academic at the same time, and how exactly to combine these qualities, Jefferson explained in his carefully designed draft of the system of education. The ultimate goal of the education system was to contribute collectively to the development of the inherent in a person's abilities and thereby to create a more just and harmonious society.

\section{REFERENCES}

[1] Journal of the Senate of the Commonwealth of Virginia. Richmond, Superintendent of Public Printing 1917, 197 p.

[2] A.G. Sytin, Political philosophy of democracy: the contribution of Thomas Jefferson. [Electronic resource]. - Access mode: http://www.politstudies.ru/files/File/2008/1/12.pdf.

[3] Ibid.

[4] Ibid.

[5] H.U. Sheldon, Political Philosophy of Thomas Jefferson: Transl. from English. - M.: Republic, 1996. 5 p.

[6] W.G. Merkel, A Founding Father on Trial: Jefferson's Rights Talk and the Problem of Slavery during the Revolutionary Period. Rutgers Law Review. 2012. 64(3), pp. 595-663.

[7] Ibid.

[8] Opinion on the French Treaties, 1793, in WTJ5: 442-43 [Electronic resource]. - Access mode: https://founders.archives.gov/documents/Jefferson/01-25-02-05620005 .

[9] M.A. Holowchak, Thomas Jefferson. The Stanford Encyclopedia of Philosophy [Winter 2016 Edition], Edward N. Zalta [ed.]. [Electronic resource]. $\quad$ - Access mode: https://plato.stanford.edu/archives/win2016/entries/jefferson/.

[10] Ibid.

[11] Russian Historical Library [Electronic resource]. - Access mode: http://rushist.com/index.php/philosophical-articles/2509-filosofiyafrensisa-bekona-kratko.

[12] E.T. Martin. Thomas Jefferson: Scientist. New York: H. Schuman. 1952 , p. 37.

[13] A Bill for the More General Diffusion of Knowledge 18 June 1779. [Electronic resource]. - Access mode: https://founders.archives.gov/documents/Jefferson/01-02-02-01320004-0079.

[14] V.V. Sorgin, Jefferson. Man, thinker, politician. - Moscow: Nauka, 1989 , p. 259

[15] A.V. Volobuev, Fundamentalism in religion, science and politics: a brief overview. Humanitarian Newsletter. No. 5 [55]. - Moscow: Publishing House MGTU named after N.E. Bauman. 201, p. 10. 